\title{
Thermally decomposed ricebran oil as a diesel fuel
}

\author{
By O. A. Megahed*, S. T. Keera**, R. I. Abdallah* and F. A. Zaher* \\ ${ }^{*}$ Fats and Oils Dept., NRC, Cairo, Egypt. \\ ${ }^{\star *}$ Egyptian Petroleum Research Institute, Cairo, Egypt.
}

\section{RESUMEN}

Descomposición térmica de aceite de germen de arroz para su uso como gasóleo

Aceite de germen de arroz, un aceite no comestible, fue descompuesto térmicamente usando diferentes cantidades de óxido cálcico como catalizador. Las propiedades combustibles del producto craqueado fueron evaluadas comparándolas con las del gasóleo. Las propiedades consideradas incluyeron el poder calorífico, punto de inflamación, viscosidad, temperatura de fluidez crítica, características de destilación, número de cetano y otras propiedades de los combustibles. Los resultados han mostrado que las propiedades combustibles del aceite descompuesto fueron bastantes similares a la de los gasóleos estándar. El poder caloríico fue del $80-90 \%$ de la del gasóleo y la viscosidad ligeramente mayor. El combustible preparado fue ventajoso sobre el gasóleo ya que el primero estaba completamente libre de sulfuro, el cual produce en la combustión del carburante gases corrosivos de óxido de azufre.

PALABRAS-CLAVE: Aceite de germen de arroz - Descomposición térmica - Propiedades combustibles.

\section{SUMMARY}

\section{Thermally decomposed ricebran oil as a diesel fuel}

Ricebran oil; a non edible oil, was thermally decomposed using different loads of calcium oxide as catalyst. The fuel properties of the cracked product were evaluated as compared to those of diesel fuel. The considered properties included the calorific value, flash point, viscosity, pour point, distillation characteristics, cetane number in addition to some other fuel properties. The results had shown that the fuel properties of the decomposed oil were quite similar to those of standard diesel fuel. The calorific value was $80-90 \%$ that of diesel fuel and the viscosity was sligthy higher. The prepared fuel was advantageous over diesel fuel as the former was completely free from sulfur, which on fuel combustion produces corrosive gases of sulfur oxides.

KEY-WORDS: Fuel properties - Ricebran oil - Thermally decomposed.

\section{INTRODUCTION}

With the gradual depletion of the world petroleum supplies, a possibility occurs that petroleum-based fuels will be available neither in sufficient quantities nor at reasonable price in the near future. This revived interest in exploring alternate fuels for automotive vehicles such as methanol, ethanol, biogas, hydrogen and vegetable oils. In order to avoid new dependencies, more interest is given recently to those altemates derived from indigenous sources and preferably renewable energy sources. Vegetable oils have the advantage of being extracted from oilseeds which are renewable sources. They have also the advantage of being ready available and liquids.

Vegetable oils show technical promise as alternative fuel for diesel engines and have good potential as emergency fuels. However, they have certain inherent problems when used as fuels in diesel engines, generally attributable to inefficient combustion. The high viscosity and low volatily of vegetable oils are responsible for most of the combustion problems of neat oils. Viscous fuels are poorly atomized in the engine resulting in inefficient combustion with subsequent formation of carbon deposits on the injector nozzle and other engine parts. Thus, the engine performance using plant oils can be markedly improved if the oil viscosity is reduced.

Several approaches have been investigated to reduce the oil viscosity by physical and chemical modifications. Chemical modification of vegetable oils to less viscous products can be made either by esterification with short chain alcohols ${ }^{(1-5)}$ or by cracking in presence of a suitable mineral catalyst ${ }^{(6-8)}$.

The present work was proposed to investigate the feasibility of utilizing thermally cracked oil as a fuel for diesel engines. Ricebran oil is produced in Egypt in considerable quantities annually as a byproduct from rice milling industry. Ricebran oil is completely unsuitable for edible purposes because it is usually hydrolysed during processing giving highly acidic products. The production rate of ricebran in Egypt during $1993 / 1994$ was about 434,570 ton which contains about 76,000 ton oil.

\section{EXPERIMENTAL}

Crude ricebran oil produced as a byproduct from rice milling industry was used in the present study.

Ricebran oil cracking was carried out in one litre reaction flask mounted in a thermostatically-temperature controlled heating mantle and attached to a condensing and receiving units. The oil, $500 \mathrm{~g}$, was mixed with calcium oxide at a load ranging between $0.5-3 \%$ of the oil weight and the mixture was then heated to 
$450{ }^{\circ} \mathrm{C}$. During the thermal cracking process, the temperature of the reaction batch and the rate of distillate formation from oil cracking were monitored. The cracking period was recorded as the time elapsed between the start and end of cracked oil distillation. The weight of the collected distillate (product) was then determined which gave an estimate for the process yield.

The cracked oil products were then tested for their fuel properties using the ASTM standard methods for petroleum products. These include the ASTM distillation characteristics (D 86-93), the kinematic viscosity (D 445-88), the flash point (D 92-90), heat of combustion (D 240-92), pour point (D 97-93), API gravity (D 28792), sulfur percentage (D 1551-68), carbon residue (D 189-88), ash percentage (D 482-91) and water content (D 96-88). Since cetane number determination by engine testing requires special equipment, as well as being time consuming and costly (ASTM D 613), estimates for the cetane number of the fuel was calculated using the following formula ${ }^{(9)}$.

$$
\text { Cetane no. }=\frac{\text { mid boiling point, }{ }^{\circ} \mathrm{C}-56}{\text { Density } \times 5}
$$

The cetane index on the other hand, was determined using a special cetane index nomograph (D 976-91) in wich this index can be cietermined according to the API gravity and mid boiling point of the fuel.

\section{RESULTS AND DISCUSSION}

The results of the present work have been used to show the effect of $\mathrm{CaO}$ load on the cracking rate and yield as well as the properties of the product as a fuel. The maximun yield is almost $70 \%$ of the starting material and the average cracking rate is $6.4 \%$ per hour. (Table 1).

Table 1

\section{Cracking Rate and Yield of Ricebran Oil Using Calcium Oxide}

\begin{tabular}{ccc}
\hline $\begin{array}{c}\text { Catalyst load, } \\
\mathrm{kg} / 100 \mathrm{~kg} \text { oil }\end{array}$ & $\begin{array}{c}\text { Maximun Yield } \\
\mathrm{kg} / 100 \mathrm{~kg} \text { oil }\end{array}$ & $\begin{array}{c}\text { Cracking rate* } \\
\mathrm{kg} / 100 \mathrm{~kg} \text { oil/hr. }\end{array}$ \\
\hline 0.5 & 7.01 & 5.4 \\
1 & 7.05 & 5.9 \\
2 & 7.15 & 7.1 \\
3 & 7.15 & 7.15 \\
\hline
\end{tabular}

* Average cracking rate using $\mathrm{CaO}=6.4 \mathrm{~kg} / 100 \mathrm{~kg}$ oil $/ \mathrm{hr}$.
The fuel properties of the cracked products compared to diesel and their distillation characteristics äre listed in Tables (2-6).

\section{(a) Distillation characteristics of the cracked products}

Distillation characteristics of a fuel exert a great influence on its performance, particularly in medium and high speed engines. The average volatility requirements of diesel fuel vary with engine speed, size and design. However, fuels having too high volatility may reduce power output and fuel economy throught vapour lock in the fuel system or inadequate droplet penetration from the nozzle.

The results of the ASTM, distillation are listed in Table (2). It can be seen that the $50 \%$ point, known as the mid boiling point for the oil cracked using $\mathrm{CaO}$ was mostly in the recommended range for the majority of automotive type diesel engines $\left(232-280^{\circ} \mathrm{C}\right)$. It can be also observed that all samples have their $90 \%$ point at close temperatures which indicates that the carbon residue from the ignition of these products will be similar ${ }^{(10)}$. However, there is some variations in the $10 \%$ point of the prepared samples which ranges between $130-175^{\circ} \mathrm{C}$. This will be reflected on the ignition starting quality being worse for the samples having their $10 \%$ point at higher temperatures.

The ASTM distillation curves have been also used to determine the product content of the fractions which have similar boiling range as diesel, kerosene and gasoline in âdditition to ts cöntént of the compoünds boiling over $350^{\circ} \mathrm{C}$. The boiling range of gasoline, kerosene and diesel were taken as 35-180, 180-250 and $230-350^{\circ} \mathrm{C}$, respectively. The volumetric percentages of those four fractions in the cracked products are listed in Table (3). It should be emphasized that the total of the four fractions may exceed $100 \%$ because of the overlapping of the boiling range of kerosene and diesel fractions.

It is obvious that the fraction which has boiling range similar to diesel fuel constitutes the major fraction in all products. The percentage of this fraction is more or less similar in most samples and its greatest level $(\sim 65 \%)$ was found in the sample cracked using $2 \% \mathrm{CaO}$. On the other hand, the volumetric percentage of the fraction which is heavier than diesel fuel ranges between $15-20 \%$ in most samples. 
Table 2

Results of ASTM Distillation of Cracked Ricebran Oil Using $\mathrm{CaO}$

\begin{tabular}{ccccc}
\hline \multirow{2}{*}{$\begin{array}{c}\text { Distilled } \\
\text { volume \% }\end{array}$} & \multicolumn{4}{c}{ Temperature ${ }^{\circ} \mathrm{C}$} \\
\cline { 2 - 5 } & $\mathbf{0 . 5} \% \mathrm{CaO}$ & $1 \% \mathrm{CaO}$ & $2 \% \mathrm{CaO}$ & $3 \% \mathrm{CaO}$ \\
\hline Initial & 72 & 60 & 78 & 85 \\
point & 72 & 102 & 115 & 98 \\
5 & 98 & 131 & 175 & 150 \\
10 & 160 & 202 & 175 \\
15 & 195 & 170 & 212 & 205 \\
20 & 215 & 175 & 212 \\
25 & 247 & 220 & 230 & 215 \\
30 & 267 & 238 & 233 & 235 \\
35 & 291 & 252 & 253 & 239 \\
40 & 300 & 266 & 256 & 259 \\
45 & 313 & 271 & 260 & 260 \\
50 & 314 & 276 & 280 & 262 \\
55 & 316 & 287 & 303 & 282 \\
60 & 318 & 305 & 313 & 305 \\
65 & 320 & 310 & 321 & 315 \\
70 & 320 & 320 & 330 & 325 \\
75 & 320 & 325 & 333 & 330 \\
80 & 320 & 327 & 333 & 333 \\
85 & 320 & 327 & 333 & 333 \\
90 & 320 & 327 & 333 & 333 \\
\hline
\end{tabular}

Table 3

Cracked Product Content of Light and heavy fractions*

\begin{tabular}{ccccc}
\hline $\begin{array}{c}\text { Catalyst } \\
\text { load } \\
\mathbf{k g} / 100 \\
\mathrm{~kg} \text { oil }\end{array}$ & $\begin{array}{c}\text { Fraction } \\
\mathbf{A}\end{array}$ & $\begin{array}{c}\text { Fraction } \\
\text { B }\end{array}$ & $\begin{array}{c}\text { Fraction } \\
\mathbf{C}\end{array}$ & $\begin{array}{c}\text { Fraction } \\
\mathbf{D}\end{array}$ \\
\hline 0.5 & 12 & 14 & 58 & 20 \\
1.0 & 22 & 11 & 58 & 15 \\
2.0 & 12 & 22 & 65 & 15 \\
3.0 & 16 & 22 & 57 & 15 \\
\hline
\end{tabular}

Fraction A: Product fraction which has similar boiling range as gasoline $\left(35-180^{\circ} \mathrm{C}\right)$.

Fraction B: Product fraction which has similar boiling range as kerosene $\left(180-250^{\circ} \mathrm{C}\right)$.

Fraction C: Product fraction which has similar boiling range as diesel $\left(230-350^{\circ} \mathrm{C}\right)$.

Fraction D: Product fraction which distills above $350^{\circ} \mathrm{C}$. (b) The fuel properties of the cracked products of ricebran oil compared to the Egyptian standard specifications of a diesel fuel

The properties of the cracked products of ricebran oil relevant to their performance as a diesel engine fuel are compared to the Egyptian standard specifications of diesel fuel in Tables (4-6).

Physical properties of the products such as API gravity, specific gravity, pour point and kinematic viscosity are recorded in Table (4). It is clear that these properties are more or less similar to those of standard diesel fuel. Regarding the viscosity of the products, it can be seen that the viscosity of ricebran oil $\left(33 \times 10^{-6}\right.$ $\mathrm{m}^{\mathrm{s}} . \mathrm{S}^{-1}$ ) has been markedly reduced by cracking to less than one third its original value. This reduced viscosity is, in most cases, very close to the maximum recommended viscosity limit according to the standard specifications. Fuel viscosity is a very important property affecting its atomization in the engine and hence its ignition properties. The atomization of the products which are slightly mole viscous than diesel fuel can be greatly improved by slight changes in the design characteristics of the engine such as the use of nozzle orifice with increased sizes.

The fuel content of water and sulfur as well as the carbon residue due to fuel combustion and the percentage ash are also important fuel properties. These affect the engine performance and the composition of the exhaust gases which may have an adverse impact on the environment. These properties are listed in Table (5). All samples are free from sulfur which if present in the fuel may give rise to low temperature sulfur corrosion owing to the fact that $\mathrm{SO}_{2}, \mathrm{SO}_{3}$ and water may condense in the colder engine parts. They are also free from non-burnable materials as detected by the ash \% which is zero in all samples. These nonbumable materials, if present, may cause some abrasion of the fuel injection components which are usually made with great precision to extremely close fits and tolerances. In addition, the ash can cause wear within the engine itself by increasing the overall deposit level and by adversely affecting the nature of the deposits.

Although the sulfur.content and ash $\%$ in the:prepared samples agree well with the standard specifications of diesel fuel, their water content is beyond the allowable limits. Water can contribute to filter blocking and cause corrosion of the injection system components. According to the standard specifications, the water content should not exceed $0.15 \%$ in diesel fuel.

It can be also observed from the listed results that the carbon residue from combustion of all cracked products is within the standard limits $(0.1 \%)$. Increased deposits of carbon due to fuel combustion in a diesel engine may cause injector coking which, in turn, results in a lot of ignition troubles due to poor fuel atomization. 
Table 4

Physical Properties of the Cracked Samples of Ricebran Oil, Compared to Diesel Fuel

\begin{tabular}{ccccc}
\hline $\begin{array}{c}\text { Catalyst load } \\
\mathrm{kg} / 100 \mathrm{~kg} \text { oil }\end{array}$ & $\begin{array}{c}\text { API } \\
\text { gravity }\end{array}$ & $\begin{array}{c}\text { Specific } \\
\text { gravity }\end{array}$ & Pour point ${ }^{\circ} \mathrm{C}$ & $\begin{array}{c}\text { Kinematic viscosity } \\
\mathrm{m}^{2} \mathrm{~S}^{-1} \times 10^{6}\end{array}$ \\
\hline 0.5 & 32.08 & 0.865 & +12 & 8.61 \\
1.0 & 35.75 & 0.846 & +6 & 7.19 \\
2.0 & 33.80 & 0.856 & 0.0 & 9.42 \\
3.0 & 33.99 & 0.855 & +6 & 9.39 \\
Diesel fuel & $31-41$ & $0.82-0.87$ & $4.5-15^{*}$ & $\leq 7$ \\
\hline
\end{tabular}

* Pour point variation according to season.

Table 5

Water Content, Sulfur Content, Ash Percentage and Carbon Residue of the Cracked Samples of Ricebran Oil, Compared to Diesel Fuel

\begin{tabular}{ccccc}
\hline $\begin{array}{c}\text { Catalyst load } \\
\text { kg/100 kg oil }\end{array}$ & $\begin{array}{c}\text { Water content } \\
\text { vol. \% }\end{array}$ & $\begin{array}{c}\text { Sulfur content } \\
\text { wt \% }\end{array}$ & $\begin{array}{c}\text { Ash } \\
\text { wt. } \%\end{array}$ & $\begin{array}{c}\text { Carbon residue } \\
\text { wt \% }\end{array}$ \\
\hline 0.5 & 0.6 & nil & nil & 0.023 \\
1.0 & 0.6 & nil & nil & 0.052 \\
2.0 & 1.2 & nil & nil & 0.039 \\
3.0 & 1.0 & nil & nil & 0.041 \\
Diesel fuel & $\leq 0.15$ & $\leq 1.2$ & $\leq 0.01$ & $\leq 0.1$ \\
\hline
\end{tabular}

Table 6

Calorific Value, Flash Point, Cetane Number and Cetane Index of the Cracked Samples of Ricebran Oil Compared to Diesel Fuel

\begin{tabular}{|c|c|c|c|c|c|}
\hline $\begin{array}{l}\text { Catalyst load } \\
\mathrm{kg} / 100 \mathrm{~kg} \text { oil }\end{array}$ & $\begin{array}{c}\text { Calorific Value } \\
\mathrm{MJ} / \mathrm{kg}\end{array}$ & $\begin{array}{l}\text { Heating value } \\
\text { compared to } \\
\text { diesel }\left.\right|^{\star \star}\end{array}$ & Flash point ${ }^{\circ} \mathrm{C}$ & Cetane number & Cetane index \\
\hline 0.5 & 40.437 & 0.91 & 54 & 59.69 & 51 \\
\hline 1.0 & 38.199 & 0.86 & 51 & 52.24 & 54 \\
\hline 2.0 & 39.675 & 0.89 & 56 & 52.26 & 52 \\
\hline 3.0 & 35.860 & 0.81 & 51 & 59.68 & 54 \\
\hline Diesel fuel & 44.3 & 1 & $\geq 55$ & $\geq 55$ & - \\
\hline
\end{tabular}

* Calorific value: Higher or gross heating value.

** Heating value compared to diesel: Calorific value of fuel/Calorific value of diesel. 
The fuel properties which are considered very important in connection with the output power, combustion noise and handling safety are the calorific value, cetane number and flash point respectively. These properties are listed in Table (6). It can be see that the cetane numbers of all samples are close to that recommended for standard diesel fuel. This indicates that these samples might produce similar combustion noise as diesel fuel. The results show also that the heating value (calorific value) of each of the prepared fuels is more than $80 \%$ of its value of diesel fuel. It follows that the power that can be produced from an engine under constant running conditions using these prepared fuels will be close to that using diesel fuel.

\section{BIBLIOGRAPHY}

1. W. E. Klopfenstein and H. S. Walker.- «Efficiencies of various esters of fatty acid as diesel fuels". - Journal of American Oil Chemists'Society 60 (1983) 1596-1598.

2. G. R. Quick and P. J. Woodmore.- "Vegetable oil ester for diesel engines" (1984) from "Vegetable oil as a diesel fuel: Status and research priorities" by Peterson, C. L.-Transactions of ASAE 29 (5) (1986) 1413-1422.
3. S. M. Geyer, M. J. Jacobus and S. S. Lestz.- "Comparison of diesel engine performance and emissions from neat and transesterified vegetable oils".-Transactions of ASE 27 (2) (1984) 375-381.

4. C. S. Hawkins and J. Fulls. - "Comparative combustion studies on various plant oil esters and the long term effects of an ethyl ester on a compression ignition engine». In "Vegetable Oils Fuels», ASAE Publication 4-82 (1982).

5. F. A. Zaher.- «Vegetable oil as alternative fuel diesel engines: A review».-Grasas y Aceites 41 (1) (1990) 82-91.

6. D. Konwer, S. E. Taylor and B. E. Gordon.-«Liquid fuels from mesua ferrea $L$. seed oils. - Journal of American Oil Chemists'Society 66 (2) (1989) 223-226.

7. A. W. Schwad, G. J. Dykstra, E. Selke, S. C. Sorenson and E. H. Pryde.- "Diesel fuel thermal decomposition of soybean oil».- Journal of American Oil Chemists'Society 65 (1988) 1781-1785.

8. F. A. Zaher and A. R. Taman.- "Thermally decomposed cottonseed oil as a diesel engine fuel».-Energy Sources 15 (1993) 499-504.

9. Utilizarea combustibilor din hidrocarburi.-Editura Technico Bucuresti, Romania (1986) C/O Mamdouh Saad, Petroleum Researches, Institute, Cairo, Egypt.

10. J. P. Allison. - "Cirieria ior quality of petroleum products?.Applied Science Publishers, LTD (1973).

Recibido: Septiembre 1997 Aceptado: Diciembre 1997 